\title{
NOTE
}

\section{Trophic responses to nutrient enrichment in a temperate seagrass food chain}

\author{
Paul H. York ${ }^{1, *}$, Brendan P. Kelaher ${ }^{1,2}$, David J. Booth ${ }^{1}$, Melanie J. Bishop ${ }^{3}$ \\ ${ }^{1}$ School of the Environment, University of Technology, Sydney, Broadway, New South Wales 2007, Australia \\ ${ }^{2}$ Batemans Marine Park, Narooma, New South Wales 2546, Australia \\ ${ }^{3}$ Department of Biological Sciences, Macquarie University, North Ryde, New South Wales 2109, Australia
}

\begin{abstract}
Simple ecological models that predict trophic responses to bottom-up forcing are valuable tools for ecosystem managers. Traditionally, theoretical ecologists have used resource-dependent functional responses to explain the modification of food chains exposed to bottom-up perturbations. These models predict alternating positive, negative and zero responses at each trophic level. More recently, ratio-dependent functional response models that predict proportional increases at each level have challenged this paradigm. The present study tested the predictions of the 2 hypotheses empirically by comparing the relative biomasses of 4 trophic levels of an estuarine seagrass food chain in relatively undisturbed, low-nutrient catchments and 'developed' catchments subjected to a prolonged period of nutrient enrichment. We found that nutrient-enriched sites had significantly greater biomass of both epiphytic algae and grazing invertebrates; however, the bottom-up forcing of nutrients was attenuated at higher trophic levels (occupied by juvenile and piscivorous fish), with no significant effect of catchment development. This disconnect in the upward cascade of energy may be due to a number of possible reasons including high levels of diversity and omnivory, trophic subsidy within the system or the strength or nature of perturbations. Although the predictions of both hypotheses failed to hold across all trophic groups, ratio dependence was prevalent at the lower levels of the food chain, which has implications for catchment management.
\end{abstract}

KEY WORDS: Trophic dynamics $\cdot$ Resource dependence $\cdot$ Ratio dependence $\cdot$ Functional response $\cdot$ Seagrass $\cdot$ Epiphytes $\cdot$ Grazers $\cdot$ Fish

Resale or republication not permitted without written consent of the publisher

\section{INTRODUCTION}

A key goal of theoretical ecology is to explain complex ecosystem processes with straightforward mathematical models (Bascompte \& Melián 2005). A classic example has been models of the movement of energy in food chains, through the relationships among consumers and their resources. Models of trophic dynamics are often based on differential predator-prey equations that determine the abundance and biomass at each trophic level in a food chain. The output of these models largely depends on their functional response, which describes the rate at which an individual predator can consume its prey as a function of prey density (Abrams \& Ginzburg 2000).
Early trophic models were based on resourcedependent functional responses, where changes in the rate of predation by an average predator are determined by the abundance of prey (Lotka 1925, Volterra 1926). More recently, ratio-dependent trophic functions (Arditi \& Ginzburg 1989), where predation rates depend on the ratio of predators to prey, have been proposed as being more representative of ecological systems. A vigorous debate has since followed (e.g. Ginzburg \& Akcakaya 1992, Abrams 1994, Bishop et al. 2006, Kratina et al. 2009) with proponents on each side claiming that their concept's predictions best mirror natural systems. There is, however, general consensus that empirical tests of each of the hypotheses are scarce (Abrams \& Ginz- 
burg 2000). The clearest difference between the 2 models occurs in predictions of community responses to sustained bottom-up pressure in a system with 4 trophic levels (Table 1).

Coastal systems, such as estuaries, provide an ideal platform to conduct field tests of resource- and ratiodependent hypotheses by correlating trophic level biomass to nutrient loading. In these systems there are generally 4 trophic levels (Vander Zanden \& Fetzer 2007), linkages between trophic levels are strong (Strong 1992) and, in recent decades, anthropogenically sourced nutrients have led to increasing enrichment (Paerl 1997). Generally, the availability of limiting nutrients is the driving bottom-up force controlling primary productivity in aquatic systems (Cloern 2001). A comparison in a phytoplankton dominated food web between sites close to and away from a sewage outfall revealed increased abundances of all 4 trophic levels proportional to nitrogen loading, therefore supporting ratio dependence (Bishop et al. 2006).

Temperate seagrass beds are an important coastal habitat which are increasingly affected by anthropogenic nutrient enrichment (Short \& Wyllie-Echeverria 1996). Excessive nutrients in seagrass systems lead to phytoplankton blooms and increased epiphytic algal growth, resulting in shading of seagrass leaves and ultimately habitat collapse (Dennison et al. 1993). The addition of more moderate amounts of nutrients may not be as devastating to the seagrasses themselves, but instead lead to changes in community structure of the epiphytic algal food webs supported by these habitats (Gil et al. 2006, Jorgensen et al. 2007). As seagrass tissue is low in nutrients and not palatable to most grazers, epiphytes contribute a large portion of the trophic support in temperate seagrass ecosystems (Moncreiff \& Sullivan 2001, Connolly et al. 2005).

Table 1. Predicted responses of trophic levels for ratio- and resource-dependent hypotheses when exposed to a sustained bottom-up forcing in food chains with 4 levels (source Ginzburg \& Akcakaya 1992). $\infty$ : a proportional response

\begin{tabular}{|c|c|c|c|}
\hline \multirow{2}{*}{$\begin{array}{l}\text { Trophic } \\
\text { level }\end{array}$} & \multicolumn{2}{|c|}{ _Hypothesis } & \multirow{2}{*}{$\begin{array}{l}\text { Seagrass } \\
\text { food chain }\end{array}$} \\
\hline & $\begin{array}{c}\text { Ratio- } \\
\text { dependent }\end{array}$ & $\begin{array}{l}\text { Resource- } \\
\text { dependent }\end{array}$ & \\
\hline 1 & $\infty \Uparrow$ & $\Downarrow$ & Epiphytic algae \\
\hline 2 & $\infty \Uparrow$ & $\Uparrow$ & Mesograzers \\
\hline 3 & $\infty \Uparrow$ & $\Rightarrow$ & Juvenile fish \\
\hline 4 & $\infty \Uparrow$ & $\infty \Uparrow$ & Piscivores \\
\hline
\end{tabular}

The present study considers the effects of longterm nutrient enrichment on a seagrass food chain that includes 4 trophic levels: epiphytic algae, grazing invertebrates, juvenile fish and piscivorous fish. The biomasses of each of 4 trophic levels were compared among 3 nutrient-enriched and 3 reference sites, to test the hypotheses that sustained bottom-up forcing will produce trophic interactions that permeate upwards through the food chain. It was also determined whether the response of each trophic level to sustained nutrient enrichment supported (1) the resource-dependent hypothesis; (2) the ratiodependent hypothesis; or (3) neither of the two, suggesting that either an alternate hypothesis needs to be developed or something other than nutrients is driving trophic interactions.

\section{MATERIALS AND METHODS}

\section{Study sites}

The study was carried out at 6 seagrass Zostera capricorni meadows in the Brisbane Water and Hawkesbury River catchments just north of Sydney, Australia $\left(33^{\circ} \mathrm{S}, 151^{\circ} \mathrm{E}\right)$. Comparisons of trophic groups were made between catchments enriched in nutrients over decades by surrounding urban industrial and agricultural development (Narara Creek, Kincumber Creek and Erina Creek), and low nutrient catchments dominated by protected native forests (Waterfall Bay, Woy Woy Bay and Patonga Creek); hereafter these are referred to as 'developed' and 'undeveloped' catchments, respectively. A comprehensive investigation of water quality using flow injection analysis (Paterson et al. 2003) had previously found significant increases of $\mathrm{NH}_{3}$ (6.6- to 8.48fold) and $\mathrm{NO}_{x}$ (4.6- to 14.2-fold) in developed catchments compared to the undeveloped reference sites. None of the sites were subject to direct commercial fishing and all were considered to have similar levels of top-down pressure from recreational fishing. There were no point sources of pollution (e.g. fish farms, sewage treatment plants, industrial effluent, etc.) in the locality of any sites.

\section{Field sampling}

The 6 sites were sampled on 3 separate occasions from October 2005 to May 2006 to compare the biomass of each trophic level within a seagrass food chain between elevated nutrient sites and low nutri- 
ent reference sites. On each occasion, 4 replicate samples $\left(0.38 \mathrm{~m}^{2}\right)$ of seagrass, epiphytes and associated epifauna separated by distances of at least $10 \mathrm{~m}$ were taken using a specially designed sampler consisting of a metal cylinder $(20 \mathrm{~cm}$ diameter $)$ with a cutting blade that slices the seagrass at the base and with a sieve (500 $\mu \mathrm{m}$ mesh) at the top that collects the sample when inverted (O'Neill et al. 2007). From each sample, epiphytic algae were scraped off 20 randomly selected seagrass leaves and invertebrates were sorted into functional groups with grazers being identified and included in the analyses. Seagrass, algae and invertebrates were dried at $60^{\circ} \mathrm{C}$ and used to determine algal load, calculated as algal biomass (g)/seagrass biomass ( $\mathrm{kg}$ ), and grazer biomass.

Four replicate $25 \mathrm{~m}^{2}$ sweeps separated by distances of at least $25 \mathrm{~m}$ were taken with a seine net $(12 \mathrm{~m}$ length, $2 \mathrm{~m}$ drop, $6 \mathrm{~mm}$ mesh) to collect small and juvenile fishes. Species known to prey upon grazing invertebrates (Burchmore et al. 1984, Edgar \& Shaw 1995) were enumerated and measured (wet weight). Larger piscivorous fish that prey upon juvenile fish were caught by hook and line using 2 lines tended for a period of $90 \mathrm{~min}$ at each site. All piscivorous fish (Baker \& Sheaves 2005, Melville \& Connolly 2005) that were caught were identified and measured (wet weight) to give catch per unit effort (CPUE) and then immediately returned to the water.

Water samples were collected from estuarine waters above seagrass beds during each sampling period and were sent to Sydney Water Analytical and Field Services laboratory for analysis of total nitrogen using the method APHA $4500-\mathrm{PH} \& \mathrm{NO}_{3}-\mathrm{I}$ (APHA et al. 2005).

\section{Statistical analyses}

Hypotheses about the effect of bottom-up forcing on the biomass of each trophic level were tested to determine if changes matched the predictions of either resource- or ratio-dependent hypotheses or neither. Because the models are based on steadystate systems, data were collected across 3 different time periods to allow for the long-term relationship among trophic groups to be used as an approximation of ecosystem equilibrium (Ginzburg \& Akcakaya 1992). Prior to analysis, data were averaged across the 3 sampling periods for each site to reduce the influence of small-scale spatio-temporal variation, which was not the focus of the hypotheses under evaluation (Keough et al. 2007). Analysis was done using $t$-tests comparing enriched versus controls with $\mathrm{n}=3$ sites. A separate $t$-test was performed on total nitrogen levels in the water column to quantify differences in nutrient levels among treatments. Prior to each test, Levene's test and graphical examination of the data using boxplots was used to check for homogeneity of variance.

To assess the prediction of increases in biomass among trophic levels proportional to the bottom-up force in the ratio-dependent hypotheses (Table 1), a single one-way ANOVA was conducted using the magnitude of change after bottom-up forcing, expressed as the ratio of nutrient-enriched sites to reference sites for the bottom-up force (nutrients) and the 4 trophic groups: epiphytes, mesograzers, juvenile fishes, and piscivorous fishes. In the event that trophic groups respond proportionately to nutrient input, no significant difference in ratios among the 5 groups should be detected. This ANOVA was followed by a posteriori Student-Newman-Keuls (SNK) tests to identify any group means that differed significantly.

\section{RESULTS}

Diverse assemblages of invertebrates, and juvenile and larger fish were collected within samples. A total of 42 taxa known to graze on algae were included in the analysis. Dominant mesograzers common among all sites included gammarid amphipods (families Maeridae, Amphilochidae and Corophiidae) and small gastropods (Diala megapicalis, Alaba sp., and Aplysiidae sp.). Of the small or juvenile fishes (<80 mm total length) sampled, 4 species (Acanthopagrus australis, and Rhabdosargus sarba Sparidae, Pelates sexlineatus Tetrapontidae and Gerres subfasciatus Gerreidae) were included in the analysis as the dominant species consuming mesograzers on seagrass leaves. Large piscivorous fishes were low in abundance and patchily distributed in space and time. Dominant species included large yellow-fin bream A. australis and long toms Strongylura leiura.

Epiphytic algal load ( $t=14.17, \mathrm{p}<0.001$, Fig. 1a), and mesograzer biomass $(t=6.49, \mathrm{p}=0.003$, Fig. $1 \mathrm{~b})$ were significantly higher at nutrient-enriched sites compared to reference sites. Juvenile fish biomass $(t=0.13, \mathrm{p}=0.902$, Fig. 1c), predatory fish biomass $(t=-0.49, \mathrm{p}=0.647$, Fig. 1d) and total nitrogen levels in water samples $(t=1.13, \mathrm{p}=0.321)$, however, showed no significant differences between treatments or across sites. The biomass ratio between ambient and nutrient-enriched catchments differed ac- 

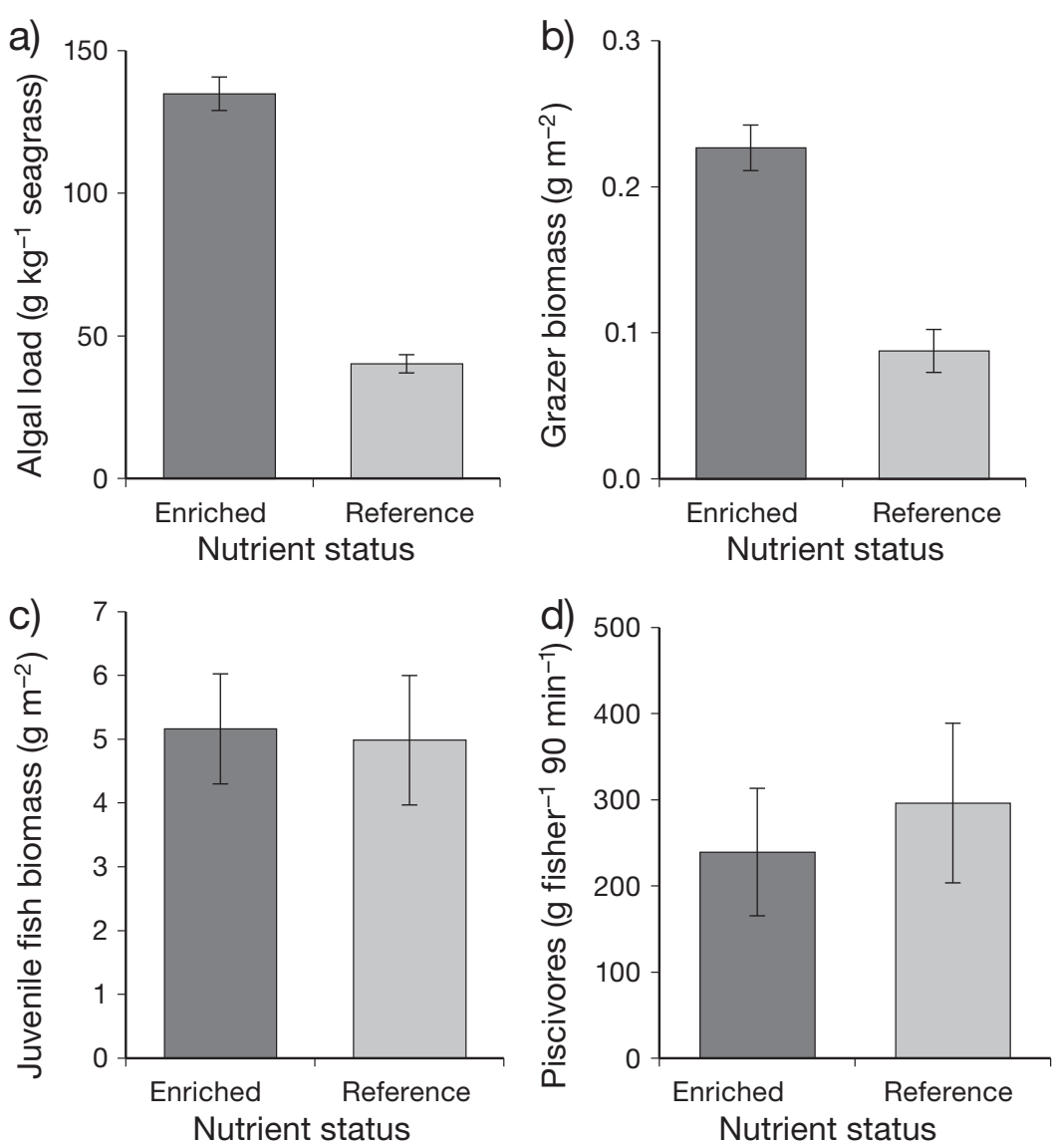

Fig. 1. Mean ( $\pm 1 \mathrm{SE}$ ) biomass of (a) epiphytes, (b) mesograzers, (c) juvenile fishes, and (d) piscivorous fishes at nutrient-enriched (dark grey bars) and reference (light grey) sites ( $\mathrm{n}=3$ in both cases)

cording to trophic level $\left(F_{4,14}=7.100, \mathrm{p}>0.06\right)$. Ratios for epiphytes (mean \pm SE: $3.7 \pm 1.0$ ) and grazers (2.6 \pm 1.5 ) were statistically similar due to the significant increases in biomass for these trophic groups (SNK, $\mathrm{p}>0.05)$; however, ratios for nutrients $(1.1 \pm 0.5)$, juvenile $(1.3 \pm 0.6)$ and piscivorous fish $(0.6 \pm 0.2)$ were significantly lower (SNK, $\mathrm{p}<0.05)$.

\section{DISCUSSION}

We have demonstrated that trophic responses in seagrass beds exposed to long-term nutrient enrichment operate more closely to ratio than resource dependence. The present study builds on the results of Bishop et al. (2006), who showed the presence of ratio dependence in a 4 level planktivorous food chain at a single site enriched by a point source of nutrients from a sewage treatment plant. The present study differed from their work by investigating enrichment from more diffuse sources and by using a more spatially comprehensive sampling design. While both studies demonstrated increased primary production and algal loads with nutrient enrichment, the present study found that in a seagrass system, secondary production was attenuated above the level of primary consumers and did not cascade through to the 2 highest trophic levels. The alternate resource-dependent hypothesis incorrectly predicts that the bottom trophic level (epiphytes) should be of lesser biomass at nutrient-enriched than reference sites.

The difference in the results from these 2 studies indicates that the strength of upward trophic cascades can vary depending on the type of ecosystem involved and the level and nature of enrichment. A recent metaanalysis of contaminants, such as nitrogen enrichment, found that point sources (e.g. fish farms and sewage treatment plants) had a positive effect on fish abundances, while diffuse sources such as run-off produced negative effects (McKinley \& Johnston 2010). It is possible that pollutants other than nutrients that are present in run-off, the main source of enrichment in this study, have negative effects on higher trophic levels, such as fish, that are not apparent in studies from point source enrichment (van der Oost et al. 2003).

The apparent dampening of the bottom-up cascade at higher trophic levels may be due to a variety of reasons. Attenuation of the upward trophic cascade from bottom-up forcing has been demonstrated in many systems (Borer et al. 2006) including seagrasses (Moksnes et al. 2008). It can be demonstrated experimentally in simple, well-understood systems that changes in the density of one trophic level do not necessarily cascade through other trophic levels due to complex direct and indirect effects (Wootton 1994). Trophic properties such as high species diversity, a high degree of omnivory, competition and intra-guild predation make systems resilient to cascading effects (Williams \& Martinez 2004, Duffy 2006). Certainly, a large number of juvenile fishes with omnivorous diets (Girella tricuspidata and Monacanthid species) inhabit seagrass beds in southeastern Australia and were at relatively high abundances during this study 
(Burchmore et al. 1984, Wressnig \& Booth 2008). Another possible explanation is that juvenile fish diets are subsidised with invertebrates from the detrital food web at reference sites where epiphyte grazers are scarce (Attayde \& Ripa 2008). Also, nontrophic factors, such as open population structures, ontogenetic habitat shifts of juvenile fish (Duffy 2006) or movement of piscivores to alternative habitats in search of food (Hindell et al. 2000), may also play a role in the decoupling of higher trophic levels from the bottom-up forcing seen at lower trophic levels.

Although no significant differences in nutrient concentrations between developed and undeveloped catchments were detected during this study, a large body of evidence has demonstrated that instantaneous measures of water column nutrients are not always indicative of nutrient loads, due to the fact that nitrogen is rapidly taken up by algae, seagrass and sediments (Lee et al. 2004, Scanes et al. 2007). This means that over-enrichment of coastal ecosystems can rarely be detected by direct measurements of water column nitrogen concentrations. Typically, urbanised catchments have more than double the nutrient loads of forested watersheds (Wahl et al. 1997) and more thorough, long-term analyses have confirmed significantly higher nutrient levels at the enriched sites used in this study (Paterson et al. 2003).

There is a paucity of studies that test the long-term effects of nutrient enrichment through food chains and allow the comparison of the predictions of both resource- and ratio-dependent hypotheses. One such study on the west coast of North America (Ware \& Thomson 2005) found a strong bottom-up link, with increased fisheries yields strongly correlated with high phytoplankton and zooplankton abundances in areas enriched by coastal upwelling and river discharge. Another synthesis of studies of eutrophication in the North Sea (Colijn et al. 2002) established a link between increases in phytoplankton production and greater biomass of zooplankton and, more tentatively, of species such as shrimp and fish in higher trophic levels. These findings support the predictions of the ratio-dependent hypothesis. Despite this, more work is required in diverse ecosystems with a range of nutrient loads and sources to establish the generality of this concept.

In our study, the predictions of neither ratio- nor resource-dependent hypotheses completely fitted the seagrass epiphyte food chain investigated. The system does, however, appear to show ratio dependence at lower trophic levels with an attenuation of trophic interactions higher in the food chain. Further studies are required to determine if this pattern of ratio-dependence at lower trophic levels holds elsewhere. Being able to predict ecosystem-level impacts of moderate nutrient enrichment is critical to enable successful estuarine management that is preventative rather than reactionary.

Acknowledgements. This research was funded by an Australian Research Council Discovery Grant (to B.P.K. and D.J.B.) and an Australian Postgraduate Award Scholarship (to P.H.Y.). We are grateful to family members, friends and students who made substantial contributions to field work. Finally, we acknowledge suggestions made by 3 anonymous thesis examiners. The study was conducted under permits issued by the NSW Department of Primary Industries (Agriculture and Fisheries Division) and the UTS Animal Care and Ethics Committee.

\section{LITERATURE CITED}

Abrams PA (1994) The fallacies of 'ratio-dependent' predation. Ecology 75:1842-1850

Abrams PA, Ginzburg LR (2000) The nature of predation: prey dependent, ratio dependent or neither? Trends Ecol Evol 15:337-341

APHA, AWWA, WPCF (2005) Standard methods for the examination of water and wastewater, 21st edn. American Public Health Association (APHA), American Water Works Association (AWWA) and Water Environment Federation (WEF), Washington, DC

Arditi R, Ginzburg LR (1989) Coupling in predator-prey dynamics: ratio dependence. J Theor Biol 139:311-326

Attayde JL, Ripa J (2008) The coupling between grazing and detritus food chains and the strength of trophic cascades across a gradient of nutrient enrichment. Ecosystems (NY) 11:980-990

> Baker R, Sheaves M (2005) Redefining the piscivore assemblage of shallow estuarine nursery habitats. Mar Ecol Prog Ser 291:197-213

> Bascompte J, Melián CJ (2005) Simple trophic modules for complex food webs. Ecology 86:2868-2873

> Bishop MJ, Kelaher BP, Smith MPL, York PH, Booth DJ (2006) Ratio-dependent response of a temperate Australian estuarine system to sustained nitrogen loading. Oecologia 149:701-708

Borer ET, Halpern BS, Seabloom EW (2006) Asymmetry in community regulation: effects of predators and productivity. Ecology 87:2813-2820

Burchmore JJ, Pollard DA, Bell JD (1984) Community structure and trophic relationships of the fish fauna of an estuarine Posidonia australis seagrass habitat in Port Hacking, New South Wales. Aquat Bot 18:71-87

Cloern JE (2001) Our evolving conceptual model of the coastal eutrophication problem. Mar Ecol Prog Ser 210: 223-253

Colijn F, Hesse KJ, Ladwig N, Tillmann U (2002) Effects of the large-scale uncontrolled fertilisation process along the continental coastal North Sea. Hydrobiologia 484:133-148

Connolly RM, Gorman D, Guest MA (2005) Movement of carbon among estuarine habitats and its assimilation by invertebrates. Oecologia 144:684-691

Dennison WC, Orth RJ, Moore KA, Stevenson JC and others 
(1993) Assessing water quality with submerged aquatic vegetation. BioScience 43:86-94

Duffy JE (2006) Biodiversity and the functioning of seagrass ecosystems. Mar Ecol Prog Ser 311:233-250

Edgar GJ, Shaw C (1995) The production and trophic ecology of shallow-water fish assemblages in southern Australia. II. Diets of fishes and trophic relationships between fishes and benthos at Western Port, Victoria. J Exp Mar Biol Ecol 194:83-106

Gil M, Armitage AR, Fourqurean JW (2006) Nutrient impacts on epifaunal density and species composition in a subtropical seagrass bed. Hydrobiologia 569: $437-447$

Ginzburg LR, Akcakaya HR (1992) Consequences of ratiodependent predation for steady-state properties of ecosystems. Ecology 73:1536-1543

> Hindell JS, Jenkins GP, Keough MJ (2000) Variability in abundances of fishes associated with seagrass habitats in relation to diets of predatory fishes. Mar Biol 136: 725-737

Jorgensen P, Ibarra-Obando SE, Carriquiry JD (2007) Topdown and bottom-up stabilizing mechanisms in eelgrass meadows differentially affected by coastal upwelling. Mar Ecol Prog Ser 333:81-93

Keough MJ, Ross DJ, Knott NA (2007) Ecological performance measures for Victorian Marine Protected Areas: review of existing biological sampling program. Technical Series 51, Parks Victoria

Kratina P, Vos M, Bateman A, Anholt BR (2009) Functional responses modified by predator density. Oecologia 159: 425-433

Lee KS, Short FT, Burdick DM (2004) Development of a nutrient pollution indicator using the seagrass, Zostera marina, along nutrient gradients in three New England estuaries. Aquat Bot 78:197-216

Lotka A (1925) Elements of physical biology. Williams \& Wilkins, Baltimore, MD

> McKinley A, Johnston EL (2010) Impacts of contaminant sources on marine fish abundance and species richness: a review and meta-analysis of evidence from the field. Mar Ecol Prog Ser 420:175-191

Melville AJ, Connolly RM (2005) Food webs supporting fish over subtropical mudflats are based on transported organic matter not in situ microalgae. Mar Biol 148: 363-371

Moksnes PO, Gullstrom M, Tryman K, Baden S (2008) Trophic cascades in a temperate seagrass community. Oikos 117:763-777

Moncreiff CA, Sullivan MJ (2001) Trophic importance of

Editorial responsibility: Just Cebrian,

Dauphin Island, Alabama, USA epiphytic algae in subtropical seagrass beds: evidence from multiple stable isotope analyses. Mar Ecol Prog Ser 215:93-106

> O'Neill KM, Schreider MJ, Glasby TM, Redden AR (2007) Lack of epifaunal response to the application of salt for managing the noxious green alga Caulerpa taxifolia in a coastal lake. Hydrobiologia 580:135-142

> Paerl HW (1997) Coastal eutrophication and harmful algal blooms: importance of atmospheric deposition and groundwater as 'new' nitrogen and other nutrient sources. Limnol Oceanogr 42:1154-1165

Paterson KJ, Schreider MJ, Zimmerman KD (2003) Anthropogenic effects on seston quality and quantity and the growth and survival of Sydney rock oyster (Saccostrea glomerata) in two estuaries in NSW, Australia. Aquaculture 221:407-426

Scanes P, Coade G, Doherty M, Hill R (2007) Evaluation of the utility of water quality based indicators of estuarine lagoon condition in NSW, Australia. Estuar Coast Shelf Sci 74:306-319

Short FT, Wyllie-Echeverria S (1996) Natural and humaninduced disturbance of seagrasses. Environ Conserv 23: $17-27$

Strong DR (1992) Are trophic cascades all wet? Differentiation and donor-control in speciose ecosystems. Ecology 73:747-754

van der Oost R, Beyer J, Vermeulen NPE (2003) Fish bioaccumulation and biomarkers in environmental risk assessment: a review. Environ Toxicol Pharmacol 13: 57-149

- Vander Zanden MJ, Fetzer WW (2007) Global patterns of aquatic food chain length. Oikos 116:1378-1388

- Volterra V (1926) Flutuations in the abundance of a species considered mathematically. Nature 118:558-560

> Wahl MH, McKellar HN, Williams TM (1997) Patterns of nutrient loading in forested and urbanized coastal streams. J Exp Mar Biol Ecol 213:111-131

> Ware DM, Thomson RE (2005) Bottom-up ecosystem trophic dynamics determine fish production in the northeast Pacific. Science 308:1280-1284

Williams RJ, Martinez ND (2004) Limits to trophic levels and omnivory in complex food webs: theory and data. Am Nat 163:458-468

Wootton JT (1994) Predicting direct and indirect effects: an integrated approach using experiments and pathanalysis. Ecology 75:151-165

Wressnig A, Booth DJ (2008) Patterns of seagrass biomass removal by two temperate Australian fishes (Monacanthidae). Mar Freshw Res 59:408-417

Submitted: August 24, 2011; Accepted: December 5, 2011 Proofs received from author(s): February 21, 2012 